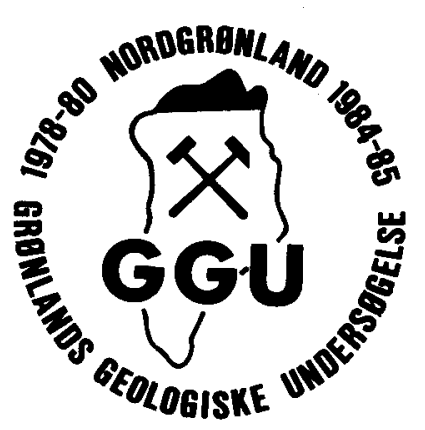

\title{
Magnetic susceptibility and palaeomagnetic collection of rocks from central and western North Greenland
}

\author{
Niels Abrahamsen and Rob Van der Voo
}

\begin{abstract}
Some 1900 orientated palaeomagnetic samples were collected from 372 sites in central and western North Greenland in 1985 covering the complete rock sequence from the Precambrian crystalline basement to the Upper Cretaceous dolerite dykes. More than 1100 susceptibility measurements from 91 sites were measured in situ on as many rock units as possible with susceptibilities above $10^{-4}$ SI units. The susceptibilities in the region span 4 orders of magnitude, but the geometrical mean values of major rock groups are well clustered and well defined suggesting that indirect subsurface mapping by aeromagnetic surveying may be a feasible tool for future investigations.
\end{abstract}

N. A., Laboratoriet for Geofysik, Aarhus Universitet, Finlandsgade 6, 8200 Arhus N, Denmark.

R. V. d. V., Department of Geological Sciences, University of Michigan, Ann Arbor, MI 48109-1063, U.S.A.

The field season of 1985 in central and western North Greenland had two main objectives: (1) collection of in situ susceptibility values ( $k$-values) of induced magnetisation for a variety of rock types; and (2) collection of a wide variety of orientated rock samples for laboratory determination of magnetic remanence directions and intensities. The susceptibility as well as the NRM (natural remanent magnetisation) will be used as background for aeromagnetic anomaly interpretation, whereas the magnetic remanence will be used for palaeomagnetic investigation of magnetostratigraphy and palaeomagnetic pole determinations. Apparent polar wander curves established from this area will be studied in relation to similar data from other parts of Greenland and the Laurentian craton (Beckmann, 1983; Marcussen \& Abrahamsen, 1983; Piper, 1982, 1984; Van der Voo et al., 1984).

An almost complete palaeomagnetic collection through the exposed rock sequence was established in 1985, and this will complement and enhance the palaeomagnetic magnetostratigraphic and polar wander investigations based on collections made during GGU's work in eastern North Greenland in 1979 and 1980 (Abrahamsen, 1980; Abrahamsen \& Marcussen, 1980; Marcussen, 1981a, 1981b; Marcussen \& Abrahamsen, 1983; Funder et al., 1985). The sum total of the palaeomagnetic collections from North Greenland covers isolated Precambrian age intervals (Archaean?, 1400-1200 Ma, 800-600 Ma), and a complete Vendian? to Silurian interval (600-400 Ma). In addition some younger time intervals are rep- 
Table 1. Summary of the 1985 palaeomagnetic sampling and the scientific objectives

\begin{tabular}{|c|c|c|c|c|}
\hline Formation/unit name & $\begin{array}{l}\text { Susceptibility } \\
\text { measurements }\end{array}$ & $\begin{array}{l}\text { Total number } \\
\text { of sites }\end{array}$ & $\begin{array}{l}\text { Total number } \\
\text { of samples }\end{array}$ & Objectives and questions to be answered \\
\hline $\begin{array}{l}\text { A. Upper Cretaceous dolerites } \\
(3 \text { generations: } \quad E-W \text {, } \\
N W-\text { SE, N-S) }\end{array}$ & Yes & 28 & 234 & $\begin{array}{l}\text { Palaeomagnetic pole determinations and } \\
\text { their bearing on Cretaceous - Tertiary plate } \\
\text { tectonics of Baffin Bay and the North Atlan- } \\
\text { tic. }\end{array}$ \\
\hline $\begin{array}{l}\text { B. Metamorphic rocks in the } \\
\text { fold belt in Nansen Land (Pol- } \\
\text { korridoren \& Paradisfjeld } \\
\text { Groups) }\end{array}$ & Yes & 27 & 117 & $\begin{array}{l}\text { Attempts to constrain or establish the age of } \\
\text { folding and/or post-metamorphic cooling. }\end{array}$ \\
\hline \multicolumn{5}{|l|}{$\begin{array}{l}\text { C. Cambrian-Silurian sedi- } \\
\text { ments }\end{array}$} \\
\hline $\begin{array}{l}\text { C1. Shelf sequence (Port- } \\
\text { fjeld Fm-Ryder Gletscher } \\
\text { Gp: Permin Land Fm, Johan- } \\
\text { sen Land Fm, Morris Bugt Gp, } \\
\text { Washington Land Group) }\end{array}$ & & 245 & 1024 & $\begin{array}{l}\text { Early Palaeozoic apparent polar wander de- } \\
\text { terminations for North Greenland and, by } \\
\text { inference, for Laurentia, and attempts to } \\
\text { establish reversal magnetostratigraphy for } \\
\text { this time. }\end{array}$ \\
\hline $\begin{array}{l}\text { C2. Deep-water sequence } \\
\text { (Lafayette Bugt \& Un-named } \\
\text { slope sequence) }\end{array}$ & Yes & 46 & 241 & $\begin{array}{l}\text { Early Palaeozoic apparent polar wander de- } \\
\text { terminations: possible tests for timing of } \\
\text { deformation and/or reheating-cooling in the } \\
\text { area. }\end{array}$ \\
\hline $\begin{array}{l}\text { D. Morænes } \varnothing \text { Formation } \\
\text { (Vendian) }\end{array}$ & Yes & 4 & 31 & $\begin{array}{l}\text { To strengthen previously obtained results } \\
\text { from Peary Land and to test palaeolatitude } \\
\text { questions related to Vendian glaciations. }\end{array}$ \\
\hline $\begin{array}{l}\text { E. Proterozoic dolerite dykes } \\
1200 \mathrm{Ma}(?)\end{array}$ & Yes & 12 & 104 & $\begin{array}{l}\text { Palaeomagnetic pole determination and cor- } \\
\text { relation/dating. }\end{array}$ \\
\hline $\begin{array}{l}\text { F. Archaean crystalline base- } \\
\text { ment }\end{array}$ & Yes & 15 & 136 & \multirow{3}{*}{$\begin{array}{l}\text { Palaeomagnetic pole determination and at- } \\
\text { tempts to relate these to Archaean plate tec- } \\
\text { tonics (if any). }\end{array}$} \\
\hline \multirow[t]{2}{*}{ Totals } & 91 sites & 372 & 1887 & \\
\hline & 34 measureme & & & \\
\hline
\end{tabular}

resented by collections from rocks affected by Ellesmerian (Devonian-Carboniferous) deformation, from Late Cretaceous dykes, and from Pliocene-Pleistocene and Quaternary sediments.

\section{Palaeomagnetic collections}

The palaeomagnetic samples were mainly collected by portable, gasoline-powered, watercooled drills. The cylindrical $(2.5 \mathrm{~cm}$ diameter) core samples were orientated mostly with a solar compass, although in about $10 \%$ of cases during cloudy weather a Brunton magnetic compass was used. At one locality, in the Precambrian crystalline basement, orientated hand-samples were collected when the drill was out of action. Depending on the objectives of the sampling programme at a given locality (see Table 1), sampling was undertaken either stratigraphically or areally, in so far as outcrop and access conditions permitted. Sampling from a given area around a camp site is referred to as a 'locality', whereas rocks sampled from a given unit (a sedimentary bed, a basement outcrop of some $4 \times 8 \mathrm{~m}$, or an outcrop of a dyke) are referred to as a 'site'. A total of 14 localities, 372 sites, and 1887 individually orientated samples are included in the present collection. For a given site, at least four, and often up to ten, individual samples were collected. 


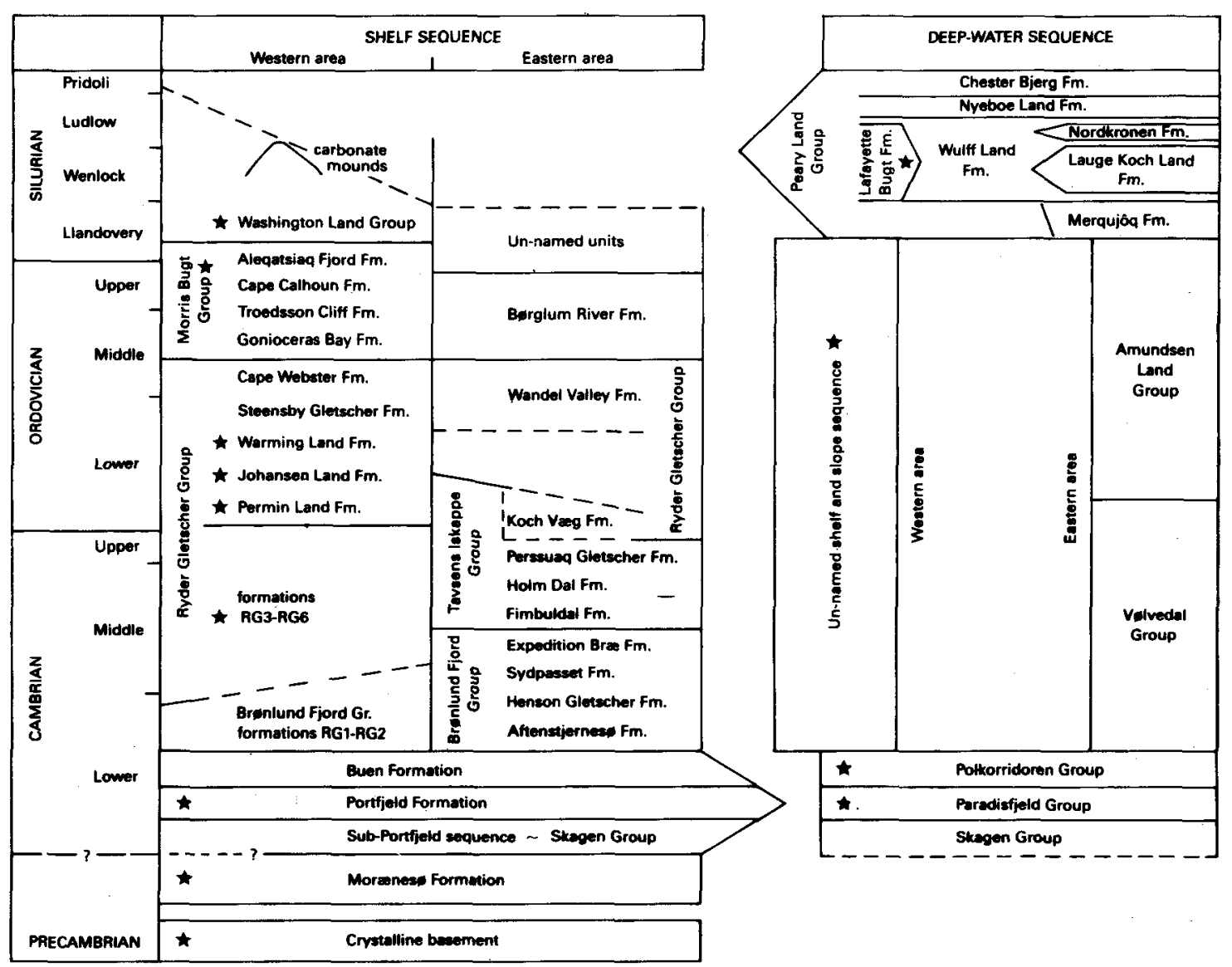

Fig. 1. Schematic stratigraphical division of the geology of central and western North Greenland. Asterisks indicate palaeomagnetically sampled units, detailed in Table 1.

For reference purposes the objectives of the magnetic field work and a summary of the material collected are given in Table 1 . The table presents a list of formations, sequences, dykes and metamorphic suites collected during the 1985 season, the relevant number of sites and samples, and the particular purpose of each sampling programme.

In fig. 1 a stratigraphic scheme is presented with the collected units marked with an asterisk. The figure, when used together with Table 1, provides an overview of the whole programme.

As is typical for any palaeomagnetic study, the collections made during the field season constitute only a first step in the study, and despite the greatest care in our selection of the most promising materials, there is no guarantee of the magnetic properties of the samples. It is not uncommon to encounter magnetic resetting in sediments and igneous rocks alike, and secondary magnetisation may be encountered in parts of the collection. This is to be expected for the more highly deformed and slightly metamorphosed formations in the northern parts of the area, and can be used to 'date' (i.e. constrain the age of) the folding or heatingcooling cycle of the Ellesmerian orogeny. 
Table 2. Susceptibility mean values for rock groups measured in situ

\begin{tabular}{|c|c|c|c|c|c|}
\hline \multirow[t]{2}{*}{ Rock group } & \multirow{2}{*}{$\begin{array}{l}\text { Number } \\
\text { of sites } \\
(\mathrm{N})\end{array}$} & \multirow{2}{*}{$\begin{array}{c}\text { Number } \\
\text { of meas. } \\
(\Sigma n)\end{array}$} & \multirow{2}{*}{$\begin{array}{c}\text { Type mean } \\
\text { susc. (log) } \\
10^{-5} \mathrm{SI}\end{array}$} & \multicolumn{2}{|c|}{ Mean error $(\log )$} \\
\hline & & & & $\begin{array}{l}\text { low } \\
\%\end{array}$ & $\underset{\%}{\operatorname{high}}$ \\
\hline \multicolumn{6}{|l|}{ Upper Cretaceous dolerites } \\
\hline 3rd generation $(E-W)$ & 10 & 109 & 1940 & -14 & +17 \\
\hline 2nd $"(\mathrm{NW}-\mathrm{SE})$ & 12 & 127 & 4000 & -11 & +13 \\
\hline lst $\quad " \quad(\mathbf{N}-\mathrm{S})$ & 6 & 78 & 1730 & -20 & +26 \\
\hline Precambrian dolerites & 10 & 142 & 3125 & -11 & +12 \\
\hline Average all dolerites & 38 & 456 & 2710 & -8 & +10 \\
\hline \multicolumn{6}{|l|}{ Sediments } \\
\hline $\begin{array}{l}\text { Group 1: Portfjeld Fm, unnamed shelf \& } \\
\text { slope seq., Morænesø Fm }\end{array}$ & 12 & 156 & 4.7 & -18 & +21 \\
\hline $\begin{array}{l}\text { Group 2: Paradisfjeld Gp, Polkorridoren } \\
\text { Gp, Silurian turbidites }\end{array}$ & 11 & 137 & 22 & -9 & +10 \\
\hline Average all sediments & 23 & 293 & 9.7 & -18 & +22 \\
\hline \multicolumn{6}{|l|}{ Precambrian crystalline rocks } \\
\hline Gneiss & 20 & 251 & 125 & -25 & +35 \\
\hline Quartz diorite & 4 & 51 & 32 & -44 & +79 \\
\hline Amphibolite & 6 & 83 & 66 & -11 & +12 \\
\hline Average all crystalline rocks & 30 & 385 & 92 & -20 & +25 \\
\hline
\end{tabular}

\section{Magnetic susceptibility}

Magnetic susceptibility $(k)$ measurements were made in situ on the outcrops using a Czech kappameter (model KT-5 susceptibility bridge) with a sensitivity of $10^{-5} \mathrm{SI}$ units). Typically 13 measurements were made per site. Logarithmic averages are summarised with information for each locality and/or rock type in Table 2.

To obtain a simple parameter for the expected mean error (i.e. 'accuracy') of the logarithmic mean value of a certain rock type, the range of the logarithmic mean error (the confidence interval of $1 \sigma$ ) was calculated by the formula

$$
\log ^{-1}\left(\log k-\mathrm{m}\left(\log k_{i}\right)\right), \log ^{-1}\left(\log k+\mathrm{m}\left(\log k_{i}\right)\right)
$$

and is indicated on Table 2 as a percentage (low and high) of the mean susceptibility of each major rock type.

The susceptibility site mean values indicated on Table 2 are illustrated in fig. 2 on a logarithmic scale, with rock type mean values and error bars.

The highest scatter in susceptibility was found in the Precambrian crystalline basement at the head of Victoria Fjord, where the site mean values for the gneisses cover more than two orders of magnitude, with a mean value for all gneiss determinations of $1.2 \cdot 10^{-3} \mathrm{SI} \pm 35$ to $25 \%$. This is about one order of magnitude above the values of the sediments and more than one order of magnitude below the various generations of dolerite dykes.

Amphibolites occur as conformable sheets in the gneisses. The measured susceptibilities are somewhat lower than the gneisses and show close clustering. Magnetically the amphi- 


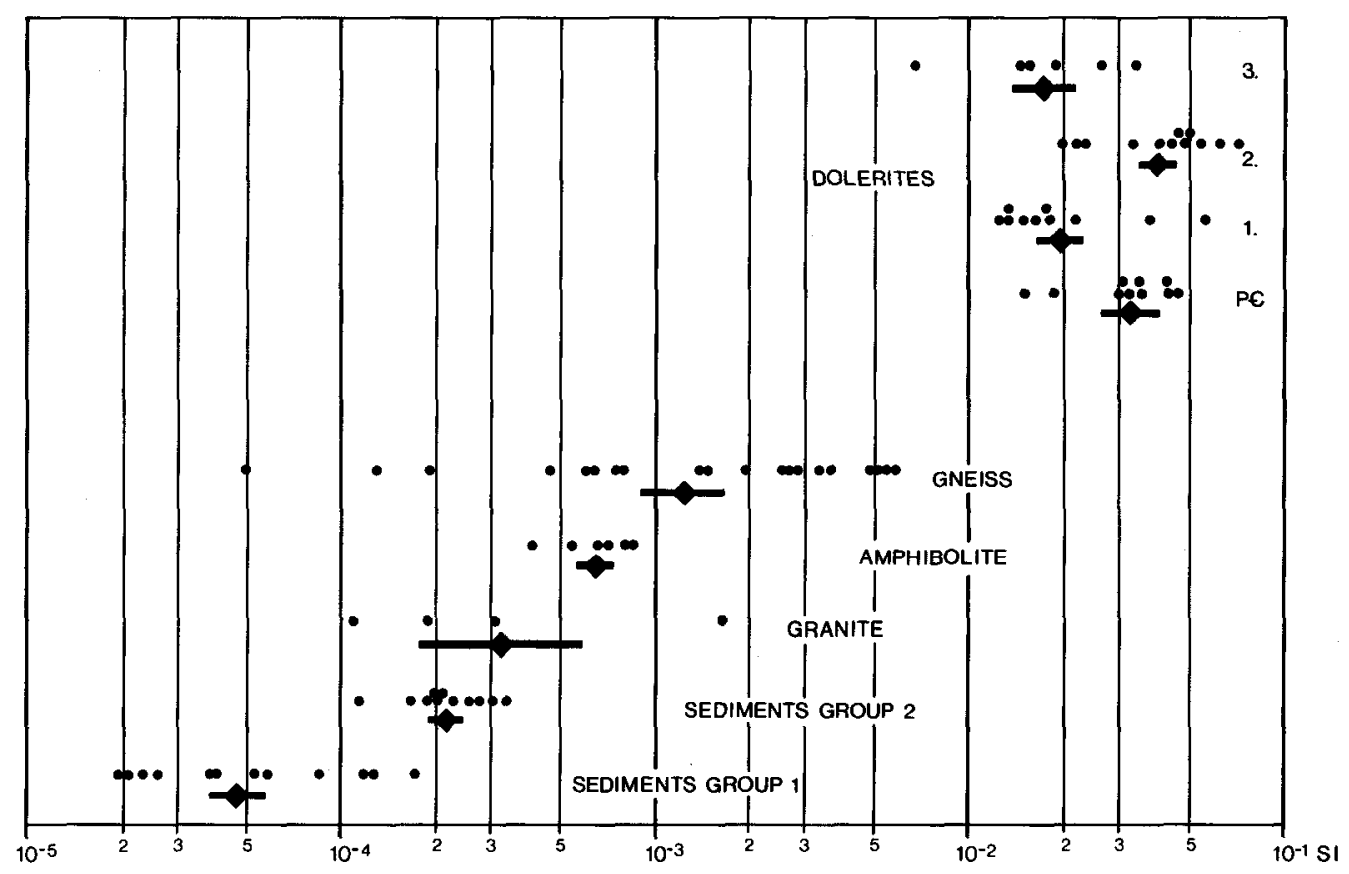

Fig. 2. Geometrical mean values of individual sites (dots) and rock type means (diamonds) with errorbars of logarithmic mean error $(1 \sigma)$, as specified in Table 2 . Dolerites are divided into a Precambrian group $(\mathrm{P} \in)$ and three generations of Upper Cretaceous dyke swarms $(1,2,3)$. See also Table 1.

bolites should probably be considered a part of the gneiss complex, as they would not be separable from the orthogneisses in an aeromagnetic survey, although their in situ measured type mean values are significantly different.

Four sites of late kinematic quartz diorites were measured on two minor intrusions of limited extent. Although the values are scattered, the mean value of $3 \cdot 10^{-4} \mathrm{SI}$ is likely to be of the right order of magnitude being on the low side for the gneiss and amphibolite mean values, and on the high side for the sediments.

The sediments are classified into two groups. Sediments with low susceptibilities between 0.2 and $1 \cdot 10^{-4} \mathrm{SI}$ are allocated to group 1 and include carbonates from the Portfjeld Formation and rocks from the unnamed shelf and slope sequence. Sediments with a moderate susceptibility around 2 to $3 \cdot 10^{-4} \mathrm{SI}$ are placed in group 2 , and include low metamorphic rock types from the Paradisfjeld Group and Polkorridoren Group. The tillite of the Morænes $\emptyset$ Formation is (arbitrarily) included in group 1, although the susceptibility values of the tillites bridge the gap between the two groups of susceptibility values. The remaining carbonates of the region, which have not been specifically measured, belong to susceptibility group 1, but they were considered to be too weakly magnetic to give meaningful measurements in the field using the kappameter.

The dolerites give site mean susceptibility values in the range 1.5 (or 0.7 in one abnormal case) to $7.2 \cdot 10^{-2} \mathrm{SI}$, which are the highest values known in this region. Four groups of dykes have been measured; one set of middle Proterozoic dolerites found in the basement gneisses 
and three generations of Late Cretaceous basic dykes found in Nansen Land (Friderichsen \& Bengaard, 1985). The susceptibility mean values of the four groups of dykes are rather well clustered with relative mean errors of typically \pm 10 to $20 \%$. A systematic high $(c . \times 2)$ mean value of the intermediate (NW-SE) generation of the Late Cretaceous dykes probably indicates a systematic higher content of $\mathrm{Fe}_{3} \mathrm{O}_{4}$, because high magnetic values are typically caused by a higher content of titanomagnetites. Combined with the systematic difference in strike (and hence stress field) of the three generations of dykes (Table 1), the high magnetic values of the intermediate NW-SE generation of dykes may hint at a slightly different type of parent magma than the other generations, e.g. caused by differential melting at different levels in the upper mantle.

\section{Conclusion}

In conclusion it may be mentioned that the maximum peak-to-peak vertical magnetic anomaly $\Delta B z$ obtained when crossing a vertical contact between two semi-infinite and very thick homogeneous formations ( $\Delta k$ is the contrast in susceptibility, and $B z$ is the vertical geomagnetic field intensity) is $\Delta B z \leq 1 / 2 \cdot \Delta k \cdot B z$ (Parasnis, 1979). With $B z=0.6 \cdot 10^{-4} T$ we may therefore expect any aeromagnetic anomaly greater than about $3 \mathrm{nT}$ (gamma) to be caused by geological structures involving rock types with contrasting susceptibilities $\Delta k \geq$ $10^{-4} \mathrm{SI}$.

The values in fig. 2 and Table 2 therefore offer important ground-based information about the relationships between susceptibilities and rock types, which may be useful in present as well as future aeromagnetic surveying and interpretations (e.g. Langel \& Thorning, 1982; Thorning, 1982, 1984).

Acknowledgements. The excellent logistic support during the field work is highly appreciated, as is the helpful advice supplied during planning by several members of the GGU expedition. Financial support for one of us (N. A.) from the Danish Natural Science Research Council (J. No. 11-3023 and -5477) is gratefully acknowledged.

\section{References}

Abrahamsen, N. 1980: Magnetic secular variation in Post-glacial marine sediments at Brønlund Fjord, Peary Land, North Greenland. Rapp. Grønlands geol. Unders. 99, 147-152.

Abrahamsen, N. \& Marcussen, C. 1980: Preliminary results of rock- and palaeomagnetic field work in Peary Land, North Greenland. Rapp. Grønlands geol. Unders. 99, 137-145.

Beckmann, G. E. J. 1983; Palaeomagnetism of some Precambrian rocks in south-east Greenland. Phys. Earth Planet. Inter. 32, 85-99.

Friderichsen, J. D. \& Bengaard, H.-J. 1985: The North Greenland fold belt in eastern Nansen Land. Rapp. Grønlands geol. Unders. 126, 69-78.

Funder, S., Abrahamsen, N., Bennike, O. \& Feyling-Hanssen, R. W. 1985: Forested arctic: evidence from North Greenland. Geology 13, 542-546.

Langel, R. A. \& Thorning, L. 1982: A satellite magnetic anomaly map of Greenland. Geophys. J. R. astr. Soc. 71, 599-612.

Marcussen, C. 1981a: En palæomagnetisk undersøgelse af Zig-Zag Dal Basalt Formationen og Midsommersødoleriterne, Peary Land regionen, det østlige Nordgrønland. Unpublished thesis, Aarhus University, $153 \mathrm{pp}$. 
Marcussen, C. 1981b: Continuation of the palaeomagnetic field work in eastern North Greenland. Rapp. Grønlands geol. Unders. 106, 95-98.

Marcussen, C. \& Abrahamsen, N. 1983: Palaeomagnetism of the Proterozoic Zig-Zag Dal basalt and the Midsommers $\varnothing$ dolerites, eastern North Greenland. Geophys. J. R. astr. Soc. 73, 367-387.

Parasnis, D. S. 1979: Principles of applied geophysics. London: Chapman \& Hall.

Piper, J. D. A. 1982: The Precambrian palaeomagnetic record: the case for the Proterozoic supercontinent. Earth planet. Sci. Lett. 59, 61-89.

Piper, J. D. A. 1984: Palaeomagnetism of the Sveconorwegian mobile belt of the Fennoscandian Shield. Precambrian Res. 23, 201-246.

Thorning, L. 1982: Processing and interpretation of aeromagnetic data in the Geological Survey of Greenland. Rapp. Grønlands geol. Unders. 114, $42 \mathrm{pp}$.

Thorning, L. 1984: Aeromagnetic maps of parts of southern and central West Greenland: acquisition, compilation and general analysis of data. Rapp. Gronlands geol. Unders. 122, $36 \mathrm{pp}$.

Van der Voo, R., McCabe, C. \& Scotese, C. R. 1984: Was Laurentia part of an Eocambrian supercontinent? In Van der Voo, R., Scotese, C. R. \& Bonhommmet, N. (edit.) Plate reconstruction from Paleozoic paleomagnetism. Geodynamics series 12, 131-136. Washington D.C.: Am. Geophys. Un. 